\title{
THE LEVEL OF KNOWLEDGE OF INVESTIGATORS AND INVESTIGATORS ASSISTANT DIRECTORATE OF GENERAL CRIMINAL INVESTIGATION OF THE NORTH SUMATERA REGIONAL POLICE ABOUT THE AUTOPSY IN 2021

\author{
Jakaria Zansen $^{\mathrm{a}}$,Agustinus Sitepu ${ }^{\mathrm{b}}$, Netty Herawati ${ }^{\mathrm{c} *}$
} \\ jackbutarbutar@gmail.com
}

Department of Forensic and Medical Sciences Faculty of Medicine, University of North Sumatera Medan - Indonesia

\begin{abstract}
Background: In this day and age, the influence of technology in the development of medical science is very high, in addition to improving the speed, accuracy and, quality of the medical profession, but it can also cause various problems both legal and medical ethics issues. Autopsy were performed on $40 \%$ to $60 \%$ of all hospital deaths in the United States before 1970. Now, this figure has dropped below 5\%. Law enforcement in Indonesia is not equipped with all kinds of science that can be used to analyze and scientifically conclude every criminal act that occurs. Previous research has shown that the level of knowledge of members of the city police sector about autopsy showed that 17 respondents out of 25 respondents had a good knowledge of autopsy, and when viewed from the age factor, 78.6\% had a good level of knowledge about autopsy, from education factors, $75 \%$ had a good level of knowledge about autopsy, from rank factors, $100 \%$ had a good level of knowledge. about the autopsy. ${ }^{33}$ Based on the background above the formulation of the problem in this study is "How is the level of knowledge of investigators and investigators assistant to the Directorate of General Criminal Investigation of the North Sumatera Regional Police about autopsy in 2021 Metode: This research is descriptive with cross-sectional design in a descriptive form that is conducted in the North Sumatera Regional Police from June 1, 2021, to August 31, 2021, with the research population of all Investigators and Investigators of the Directorate of General Criminal Investigation of the North Sumatera Regional Police and Samples on this study are Investigators and Investigators assistant to the North Sumatera Regional Police Directorate of General Criminal Investigation that marked handle the consent sheet as a sample and who fills out the questionnaire sheet. The technique in sampling in this study using total sampling, namely sampling all Investigators and Investigators Assistant Directorate of General Criminal Investigation of the North Sumatera Regional Police where the data have listed the variables to be examined by the specific purpose of this study. Data is collected and recorded and tabulated with the type of variable to be studied. Results: Based on the results of research and data analysis on the Level of Knowledge of investigators and assistant investigators of the general criminal investigation directorate of the North Sumatera Regional Police about the Autopsy in 2021, several points of conclusion can be drawn: (1). The majority of respondents had a good knowledge of autopsy, namely as many as 72 good respondents (90\%)and 8 respondents moderate (10\%). (2). Judging from the age factor, the age level that has good knowledge is between 36-45 years, which is as many as 35 respondents (94.59\%). (3). Judging from the education factor, the majority of respondents who have good knowledge are respondents who are educated Bachelor and Master, namely Bachelor as many as 59 respondents $(92.19 \%)$ and Master as many as 1 person $(100 \%)$. (4). Judging from the rank factor, the majority of respondents who have good knowledge are the rank of Second Police Inspector Adjutant, First Police Inspector Adjutant, Second Police Inspector, First Police Inspector, Police Commissioner Adjutant and, Police Commissioner which is $100 \%$.
\end{abstract}

Keywords: Autopsy, Investigator, Level of Knowledge, Police

\section{Introduction}

In this day and age, the influence of technology in the development of medical science is very high, in addition to improving the speed, accuracy, and quality of the medical profession, but it can also cause various problems both legal and medical ethics problems. For example, in a criminal case, to find out the cause of death of the victim then the act of dissection of the body (autopsy). However, generally, the victim's family does not allow it because it is considered to hurt the victim, damage the corpse, and contrary to human values.

Autopsy were performed on $40 \%$ to $60 \%$ of all hospital deaths in the United States before 1970. Now, this figure has dropped below $5 \%$ at this institution experiencing a 20-fold decrease in the number of autopsy performed in 2016 compared to the 1970s.

Law enforcement in Indonesia is not equipped with all kinds of science that can be used to analyze and scientifically conclude every criminal act that occurs. As for before the follow-up examination of the body, investigators are required to explain to the family the purpose and purpose of the surgical examination of the body as written in article 134 of the Indonesian Criminal Procedure Code. But in the reality that we face in the field at the hospital that provides autopsy services at the installation of the mortuary, there are still many requests Visum et Repertum victims die only requests for external examination only without an examination (autopsy), this is due to whether there is still a lack of understanding of police members about the autopsy and the purpose and benefits of doing an autopsy so that it can not explain properly. The benefits of the autopsy to the community so that it gets a rejection from the community both from family members of victims, community leaders, religious leaders, tribal chiefs, village government officials, and certain communities for autopsy. 
Previous research has shown that the level of knowledge of members of police sector pancur batu about autopsy 17 of the 25 respondents had a good knowledge of the autopsy, and when viewed from factor age,78.6\% have a good level of knowledge about autopsy, from factor Education, 75\% have a good level of knowledge about autopsy, from factor Rank, 100\% have a good level of knowledge about autopsy.

An autopsy is an examination of the body including external and internal examinations using a way that can be scientifically accounted for by authorized and competent experts (Sofwan Dahlan; 2019) (Setyo Trisnadi; 2019) Faculty of Medicine Unissula. The implementation of the forensic autopsy is regulated in the Indonesian Criminal Procedure Code, which in principle the autopsy is carried out if there is a written request letter from the investigator and after the family has been briefed and has understood it or after two days in the case in the family does not approve the autopsy or the family is not found. The benefit of this autopsy is to clear a criminal case, for the investigation process can be useful for the disclosure of crime cases that are hampered and have not been resolved completely. (Soeparmono, 2002)

In the Regulation of the Head of the State Police of the Republic of Indonesia Number 6 of 2019 concerning Criminal Investigations, In Chapter, I Article 1 it is explained that investigators are police officers who are authorized by law to conduct investigations. In the Government Regulation of the Republic of Indonesia Number 58 of 2010 concerning Changes to Government Regulation No. 27 of 1983 concerning the Implementation of the Criminal Procedure Law Book explained in article 2A paragraph a that: investigators rank the lowest Level Inspector of Two Police and educated at least undergraduate strata one or equivalent

Knowledge is the result of 'knowing', and this happens after a person has perceived a particular object. The results of Rogers's research (1974) and notoadmojo (2003), revealed that before respondents adopt new behaviors (new behavior), in the person becomes a sequential process, namely: Awareness, Interest, Evaluation, Trial, and Adoption. The knowledge covered in the cognitive domain has 6 levels, namely: Know, Understanding, Application, Analysis, Synthesis, and Evaluation. According to Notoadmojo several factors affect knowledge, namely: Education Level, Culture, Experience, Information, and Socioeconomic status.

So far there has been no research on the level of knowledge of investigators of the North Sumatera Regional Police general criminal section about autopsy, based on the description of the background above the author is interested in knowing the level of knowledge of investigators and investigators assistant directorate of general criminal investigation of the north sumatera regional police about the autopsy.

\section{Research Methodology}

This research is descriptive with cross-sectional design in descriptive form conducted in the North Sumatera Regional Police from June 1, 2021, to August 31, 2021, with the research population of all Investigators and Investigators Assistant Directorate of General Criminal Investigation of North Sumatera Regional Police and Samples in this study, are Investigators and The Assistant Investigator of the North Sumatera Regional Police Directorate of General Criminal Investigation who signed the approval sheet as a sample and who filled out the questionnaire sheet. The technique in sampling in this study using total sampling, namely sampling all Investigators and Investigators Assistant police of North Sumatera Regional Police Directorate general criminal where. In the data are listed the variables that will be examined by the specific purpose of this study. Data is collected and recorded and tabulated with the type of variables, namely based on age, education level, and level of level. The data obtained by researchers will be processed using descriptive statistics. All results from the questionnaire were collected and assessed according to the above theory regarding the level of knowledge, namely: Good: if the total value obtained is 11-15, Medium: if the total score obtained is 6-10, Less: if the total value obtained is $0-5$, The measuring instrument in this research is a questionnaire with 15 questions, namely 15 questions for knowledge about autopsy, The measurement method is a questionnaire that has a score of 1 for questions that are answered correctly, a score of 0 for questions that are answered incorrectly. The result of the measure in this study is the total score of the questions given.

\section{Result}

Out of a total of 80 respondents, the level of knowledge of investigators and investigators assistant directorate of general criminal investigation of the North Sumatera regional police about autopsy, the result from questioner are 72 respondents (90\%) have good knowledge and 8 respondents $(10 \%)$ have moderate knowledge.

Description of the characteristics based on age category of the respondents from total of respondents are 80 persons, there are 10 respondents aged between $17-25$ years, 8 respondents ( $80 \%$ ) have good knowledge about autopsy, 2 respondents (20\%) have moderate knowledge. Between 25 respondents aged 26-35 years, 22 respondentss (88\%) have good knowledge of autopsy, 3 respondents (12\%) have moderate knowledge. From 37 respondents aged 36-45 years 35 respondents (94.59\%) have good knowledge of autopsy, 2 respondents $(5.41 \%)$ have moderate knowledge, and between 8 respondents aged 45-54 years, 7 respondents $(87,5 \%)$ have good knowledge of autopsy and 1 respondent $(12,5 \%)$ have moderate knowledge. The level of knowledge of investigators and investigators assistant directorate of general criminal investigation of the north sumatera regional police about the autopsy knowledge based on aged 36-45 years 35 respondents $(94.59 \%)$ have good knowledge.

Description of the characteristics based on education category of the respondents from total of respondent: 5 parfeg 80 persons, the knowledge level of 15 respondents who were high school educated, 12 respondents (80\%) had good knowledge about autopsy, 3 respondents $(20 \%)$ had moderate knowledge. From 64 respondent who were Bachelor educated, 59 respondents (92.19\%) had 
good knowledge of autopsy, 4 respondents $(7.81 \%)$ had moderate knowledge. And 1 respondent who were on Master educated has good knowledge (100\%). The level of knowledge of investigators and investigators assistant directorate of general criminal investigation of the north sumatera regional police about the autopsy based on education who have good knowledge are respondents who are educated Bachelor and Master, which is as many as 59 respondents (92.19\%) who were Bachelor. And 1 responden (100\%) who were Master.

Description of the characteristics based on rank category of the respondents from total of respondents are 80 persons,, the level of knowledge of 6 respondents who ranked Second Police Brigadier, 5 respondents (83.33\%) had good knowledge about autopsy, 1 person (16.67\%) had moderate knowledge. From the 6 respondents with the rank of First Police Brigadier, 5 respondents $(83.33 \%)$ have good knowledge about autopsy, 1 person $(16.67 \%)$ has moderate knowledge. From the 16 respondents of brigadier rank, 13 respondents $(81.25 \%)$ have good knowledge and 3 respondents $(18.75 \%)$ are knowledgeable moderate. From the 19 respondents with Chief Police Brigadier rank, 16 respondents $(84.21 \%)$ have good knowledge and 3 respondents $(15.79 \%)$ have moderate knowledge. From the 8 respondents with Second Police Inspector Adjutant rank, all respondents (100\%) had good knowledge of autopsy. From the 8 respondents with First Police Inspector Adjutant rank, all respondents (100\%) had good knowledge of autopsy. Of the 5 respondents of Second Police Inspector rank, all respondents (100\%) have good knowledge of autopsy. From the 7 respondents of First Police Inspector rank, all respondents (100\%) are well informed about autopsy. From the 2 respondents with the rank of Police Commissioner Adjutant, all respondents (100\%) are well informed about autopsy From 3 respondents with the rank of Police Commissioner, all respondents (100\%) are well informed about autopsy. The level of knowledge of investigators and investigators assistant directorate of general criminal investigation of the north sumatera regional police about the autopsy based on rank who have good knowledge are First Police Inspector Adjutant, Second Police Inspector, First Police Inspector, Police Commissioner Adjutant and Police Commissioner.

\section{Discussion}

Of the total 80 respondents , the level of knowledge of investigators and assistant investigators of the general criminal investigation directorate of the North Sumatra regional police about autopsy. Judging from the age factor, the age level who has good knowledge is between 36-45 years, as many as 35 respondents (94.59\%). According to Mubarak (2013), a person's knowledge is also influenced by: education, age, and years of service. Education means the guidance given by one person to another towards something. It is undeniable that the higher a person's education, the higher they receive information and in the end the more knowledge they have. On the other hand, if someone has a low level of education, it will hinder the development of a person's attitude towards receiving information and values that have just been introduced. Judging from the education factor, shows that the majority of respondents who have good knowledge are respondents with Bachelor education and Master education, as many as 59 respondents (92.19\%) Bachelor and 1 person (100\%) Master. This means that the higher the education of the respondents, the better their knowledge about autopsies. This is in accordance with the opinion of Notoatmodjo (2014) which says that education is one of the factors that influence knowledge. The higher the education, the easier it will be to accept new things and adapt easily to the new things. In other words, the higher the education, the more opportunities to have higher knowledge, including in the health sector. Judging from the rank fator, it can be seen from the result that the majority of respondents who have good knowledge are First Police Inspector Adjutant, Second Police Inspector, First Police Inspector, Police Commissioner Adjutant and Police Commissioner which is 100\%. Descriptive analysis results showed that the majority of respondents had good knowledge of autopsy, which was 72 respondents $(91.25 \%)$. Judging from the age factor, the age level that has good knowledge is between 36-45 years, which is as many as 35 respondents $(94.59 \%)$. Judging from the level of knowledge respondents based on education who have good knowledge are respondents who are educated Bachelor and Master, namely Bachelor as many as 59 respondents (92.19\%) and Master as many as 1 person $(100 \%)$. This means that the higher the education of respondents, the better their knowledge of autopsy. Judging from the level of knowledge of respondents based on the rank of Second Police Inspector Adjutant, First Police Inspector Adjutant, Second Police Inspector, First Police Inspector, Police Commissioner Adjutant, and Police Commissioner which is $100 \%$. This means that the higher the rank of the respondent, the higher his knowledge of the autopsy.

\section{Conclusion}

Based on the results of research and data analysis from 80 respondents on the Level of Knowledge of investigators and investigators assistant Directorate of General Criminal Investigation of North Sumatera Regional Police about Autopsy in 2021, majority of respondents had a good knowledge of autopsy, which were 72 respondents (90\%) have good knowledge and 8 respondents $(10 \%)$ have moderate knowledge. Judging from the age factor, the age level that has good knowledge is between 3645 years, which is as many as 35 people $(94.59 \%)$. Judging from the education factor, the majority of respondents who have good knowledge are respondents who are educated Bachelor and Master, Bachelor as many as 59 people (92.19\%) and Master as many as 1 person (100\%). Judging from the rank factor, all respondents who have good knowledge on rank Second Police Inspector Adjutant, First Police Inspector Adjutant, Second Police Inspector, First Police Inspector, Police Commissioner Adjutant, and Police Commissioner, which is $100 \%$. 


\section{Suggestion}

To investigators at the North Sumatra Regional Police or North Sumatra Regional Police, it is recommended to continue to increase their knowledge of autopsies on aspects that require better communication with the families of victims who require autopsy, so that the implementation of autopsies can be optimaled. Provide socialization to the public regarding the purpose of the autopsy so that public knowledge can increase and the public can accept/approve the autopsy to assist investigators in upholding justice, and to maintain their knowledge of autopsies so that autopsies can be carried out more effectively. Finnaly to other researchers, it is recommended to conduct similar research with a wider research scale to obtain more accurate results of the latest research.

\section{Acknowledgements}

I would like to thank you for directorate of general criminal investigation of the north sumatera regional police for conducting this research.

\section{References}

Abdussalam, 2006. Forensik. Jakarta: Restu Agung.

Afandi, D, 2008. Visum Et Repertum pada Orang Mati. Skripsi, Universitas Sumatra Utara.

Afif, F, 2010, Fungsi Visum Et Repertum dalam Proses Penyidikan Kasus Tindakan Pidana .Penganiayaan. Skripsi, Universitas Andalas.1,Sumatera Barat.

Aksara. Mubarak, W.I., Chayatin, N., Rozikin, K., Supradi. 2013. Promosi Kesehatan Sebuah Pengantar Proses Belajar Mengajar dalam Pendidikan. Yogyakarata: Graha Ilmu .

Amir, A, 1995. Rangkaian Ilmu Kedokteran Forensic. Medan: Ramadhan.

Arikunto,S, 2007. Analisa Data Penelitian Deskroptif. Dalam: Arikunto, S., ed. Menajemen Penelitian. Jakarta: Rineka Cipta.

Dahlan, S, \& Trisnadi, S, 2019. Ilmu Kedokteran Forensik, Unissula, Fakultas Kedokteran, Semarang.

Hamzah, A, 1996. Hukum Acara Pidana Indonesia. Jakarta: Sinar Grafika.

Idries, AM, 2009. Pedoman Praktis Ilmu Kedokteran Forensik Bagi Praktisi Hukum Jakarta: Sagung Seto.

Idris, AM, 1997. Pedoman Ilmu Kedokteran Forensik Edisi Pertama. Jakarta: Binarupa.

Notoadmodjo, S, 2003. Ilmu Kesehatan Masyarakat. Jakarta: Rineka Cipta.

Notoadmodjo, S, 2005. Promosi Kesehatan dan Ilmu Prilaku. Jakarta : Rineka cipta.

Notoadmodjo, S, 2010. Metodologi Penelitian Kesehatan. Jakarta: Rineka Cipta.

Pratiwi, T, 2010. Penerpan Sanksi Pidana yang Dilakukan Secara Berlajut Dipengadilan Negri Karanganya. Skripsi, Universitas Sebelas Maret.

Sastroasmoro, S. \& Ismael, sofyan, 1995. Dasar-Dasar Metodologi Penelitian Klinis.

Soularto, Dirwan Suryo dan Eka Siwi Dwi Cahyanti,2009. Analisis Kualitas.

Situmorang Histar, Peranan Visum et Repertum dalam tindak pidana Penganiayaan yang mengakibatkan kematian. Skripsi. Universitas Sumatera Utara. 2007.

http:/medan.tribunnews.com/2020/01/02angka-kriminalitas-di-sumut-2019-tergolong-tinggi-total-31388-kasus-tertinggi-kejahatan-narkoba.

http://bphn.go.id/data/documents/10pp058.pdf

http://p2k.unugha.ac.id/id1/2-3050-2947/Tanda-Kepangkatan-Polri_43401_p2k-unugha.html

https://humas.polri.go.id/download/peraturan-kepala-kepolisian-negara-republik-indonesia-nomor-6-tahun-2019-tentang-penyidikan-tindak-pidana/

Hamzah, A,Hukum Acara Pidana Indonesia. Jakarta: Sinar Grafika. 1996.

S. Notoadmodjo, Ilmu Kesehatan Masyarakat, Jakarta Rineka Cipta , 2003.

https://www.kpk.go.id/images/pdf/Undang-undang/uu_8_1981.pdf

https://www.ncbi.nlm.nih.gov/pmc/articles/PMC5724047/

http://jos.unsoed.ac.id/index.php/jfmi/article/download/2649/1458/

https://ijtihad.iainsalatiga.ac.id/index.php/ijtihad/article/download/2793/pdf

http://jurnal.usu.ac.id/index.php/jmpk/article/download/17154/7241

https://ojs.unud.ac.id/index.php/eum/article/download/63000/36010/

Sembiring Erwin. Tingkat Pengetahuan Anggota Kepolisian Sektor Kota Pancur Batu Tentang Autopsi(Tesis). Medan: Fakultas Kedokteran Universitas Sumatera Utara; 2021. 